\title{
Effect of the presence of partially sulfonated polyaniline on the proton and methanol transport behavior of partially sulfonated PVdF membrane
}

\author{
Kingshuk Dutta, Suparna Das and Patit P Kundu \\ Poly(vinylidene fluoride) (PVdF) and polyaniline (PAni) were partially sulfonated using chlorosulfonic acid (CSA) as the \\ sulfonating agent. Partially sulfonated PVdF (SPVdF) having a degree of sulfonation (DS) of $\sim 22 \%$ and partially sulfonated PAni \\ (SPAni) having a DS of $\sim 29 \%$ were blended at constituent wt\% ratios of SPVdF:SPAni $=95: 5,90: 10,85: 15$ and 80:20 to \\ fabricate different blend membranes. These blend membranes exhibited extremely low methanol uptake and methanol \\ permeability, as well as high membrane selectivity ratios (especially at high methanol concentrations). The blend membranes \\ also exhibited superior water uptake capacity, water swellability, ion-exchange capacity (IEC) and proton conductivity compared \\ with pristine PVdF and SPVdF membranes. The SPVdF:SPAni (80:20) blend membrane was found to produce the lowest \\ methanol permeability values of $1.50 \times 10^{-9} \mathrm{~cm}^{2} \mathrm{~s}^{-1}$ (at $2 \mathrm{~m}$ methanol) and $6.30 \times 10^{-9} \mathrm{~cm}^{2} \mathrm{~s}^{-1}$ (at $8 \mathrm{~m}$ methanol) and the \\ highest membrane selectivity values of $3.27 \times 10^{6} \mathrm{Ss} \mathrm{cm}^{-3}$ (at $2 \mathrm{~m}$ methanol) and $7.78 \times 10^{5} \mathrm{Ss} \mathrm{cm}^{-3}$ (at $8 \mathrm{~m}$ methanol). \\ However, the introduction of Nafion to the SPVdF/SPAni blend membrane to form a ternary blend membrane (that is, SPVdF: \\ Nafion:SPAni $=50: 30: 20)$ resulted in much improved IEC and proton conductivity.
}

Polymer Journal (2016) 48, 301-309; doi:10.1038/pj.2015.106; published online 4 November 2015

\section{INTRODUCTION}

The fabrication of membranes with low methanol permeability has been of considerable interest for several years now, especially for application as a polymer electrolyte in direct methanol fuel cells (DMFCs). ${ }^{1-9}$ Two different approaches have been adopted for such fabrications, that is, (a) the utilization of inherently methanophobic materials as membrane co-constituents and (b) the reduction/blocking of methanol flow channels by the introduction of a second co-constituent (primarily hydrophilic and proton conducting) within the base polymer by means of blending, grafting and coating. ${ }^{10-18}$ Blending two or more different polymers, of which one polymer (which is the main constituent by weight) is methanophobic and the other(s) is hydrophilic and proton conducting, has been the most favored route for fabricating highly methanol-resistant and selective membranes. ${ }^{19-25}$ In addition, the costs of the membrane materials and the membrane fabrication process should be maintained as low as possible in order to enhance the commercial viability of these membranes.

A number of such potential materials has been reported by the authors of this work, such as pure and partially sulfonated poly (vinylidene fluoride) (SPVdF) and its copolymer, pure and partially sulfonated polyaniline (PAni and SPAni), polybenzimidazole and sulfonated polystyrene. Utilization of the abovementioned polymers has led to the fabrication of blended, coated and composite membranes exhibiting low methanol permeabilities and high membrane selectivities. ${ }^{26-32}$ The promising results obtained thus far have provided sufficient motivation to venture into the fabrication of other potential low-cost and methanol-resistant membranes. Blend membranes composed of SPVdF and Nafion have also exhibited highly methanol-resistant and proton-conducting properties. ${ }^{32}$

In this work, the fabrication of highly methanol-resistant blend membranes composed of SPVdF and SPAni was demonstrated. The fabricated blend membranes were also analyzed for their water uptake (WU) capacity, water swelling ratio (SR), methanol uptake (MU) capacity, ion-exchange capacity (IEC), proton conductivity and membrane selectivity. The obtained results were compared with those of pristine PVdF and SPVdF membranes. In addition, it was realized that the introduction of Nafion to the SPVdF/SPAni blend membrane, thereby forming a ternary blend membrane (that is, SPVdF:Nafion: SPAni $=50: 30: 20$ ), resulted in much improved IEC and proton conductivity.

\section{EXPERIMENTAL PROCEDURE}

Materials and instruments

Aniline (Ani), ammonium persulfate, PVdF ( $\left.\mathrm{M}_{\mathrm{w}}: 530000\right)$ and Nafion resin ( $5 \mathrm{wt} \%$ solution in a mixture of lower aliphatic alcohols and water, density: $0.924 \mathrm{~kg} \mathrm{~m}^{-3}$ ) were purchased from Sigma-Aldrich (Sigma-Aldrich Corporation, St Louis, MO, USA). Reagent-grade $\mathrm{HCl}$ was purchased from Loba 
Chemie (Loba Chemie Pvt. Ltd, Mumbai, India). Chlorosulfonic acid (CSA), methanol, acetone, 1,2-dichloroethane and NMP ( $N$-methyl-2-pyrrolidone) were obtained from Merck Millipore India (Merck Life Science Pvt. Ltd, Bangalore, India). All chemicals were used as received. De-ionized water was used for all experiments. Fourier transform infrared spectroscopic (FT-IR) characterization of the prepared blend membranes was performed using a Bruker Alpha (Bruker Corporation, Billerica, MA, USA) FT-IR spectrophotometer (Model: Alpha E) at $20^{\circ} \mathrm{C}$. The wavenumber window employed was from $500 \mathrm{~cm}^{-1}$ to $4500 \mathrm{~cm}^{-1}$. X-ray diffraction (XRD) analyses of the membranes were conducted using a goniometer by applying (a) an angle of $2 \theta$, (b) a range of $0-50^{\circ}$ and (c) a fixed scan rate of $1^{\circ} \mathrm{min}^{-1}$. Percentage of crystallinity values of the membranes were calculated following the procedure as reported previously. ${ }^{27} \mathrm{~A}$ Gamry (Gamry Instruments Inc., Warminster, PA, USA) Potentiostat- 600 was used to determine the proton conductivities of the membranes. An applied potential of $10 \mathrm{mV}$ and a frequency range of $1-10^{5} \mathrm{~Hz}$ were employed for this purpose. An Optizen (Mecasys Co. Ltd, Ramsey, MN, USA) UV-Vis spectrophotometer was employed to analyze the methanol permeabilities of the membranes. The morphologies of the fabricated membranes were investigated by employing a ZEISS (Carl Zeiss AG, Oberkochen, Germany) scanning electron microscope. A universal tensile testing machine (Nexygen plus, Lloyd Instruments Ltd, West Sussex, UK) was used to determine the tensile strengths of the membrane samples. ASTM D 882-02 procedure was adopted for this purpose. A 5-T tensiometer at a crosshead speed of $5 \mathrm{~mm} \mathrm{~min}-1$ and at a temperature of $25^{\circ} \mathrm{C}$ was employed.

\section{Polymerization and partial sulfonation procedures}

A total of $0.1 \mathrm{M}$ Ani was oxidatively polymerized to PAni in an acidified aqueous solution using $0.1 \mathrm{~m}$ ammonium persulfate as an oxidant. The obtained polymer was filtered and vacuum-dried. ${ }^{33}$ These vacuum-dried PAni granules were sulfonated by CSA at $80^{\circ} \mathrm{C}$ for $5 \mathrm{~h}$ with constant stirring. This solution was then added drop-wise to $200 \mathrm{ml}$ of methanol maintained at $0-5^{\circ} \mathrm{C}$, followed by the addition of $100 \mathrm{ml}$ of acetone. The resulting green powder precipitate was filtered, washed and vacuum-dried. ${ }^{28-30,34}$

PVdF granules were first vacuum-dried for a period of $12 \mathrm{~h}$ at a temperature of $60^{\circ} \mathrm{C}$. The sulfonation reaction was carried out in a round-bottom flask containing CSA and PVdF under continuous stirring for $2 \mathrm{~h}$ at $50^{\circ} \mathrm{C}$. The obtained black pellets were then collected, washed sequentially with 1,2-dichloroethane, $100 \%$ methanol and water and finally vacuum-dried at $60^{\circ} \mathrm{C}$.

\section{Preparation of the blend membranes and their pretreatments}

The SPVdF/SPAni binary blend membranes were fabricated using constituent $\mathrm{wt} \%$ ratios of SPVdF:SPAni= 95:5, 90:10, 85:15 and 80:20. The SPVdF/Nafion/ SPAni ternary blend membrane was fabricated with a constituent wt $\%$ ratio of SPVdF:Nafion:SPAni $=$ 50:30:20. The abovementioned polymer blends were separately dissolved in NMP (under stirring) at $60^{\circ} \mathrm{C} \cdot{ }^{28-30}$ The resulting blend solutions were then cast onto flat glass plates and kept at $80^{\circ} \mathrm{C}$ for drying. It should be noted that an increase in SPAni content beyond $20 \mathrm{wt} \%$ resulted in rapid deterioration of the mechanical strength of the corresponding blend membrane.

The binary blend membranes were treated by immersion into $5 \mathrm{M} \mathrm{H}_{2} \mathrm{O}_{2}$ solutions, followed by treatment with a mixture of water and $\mathrm{H}_{2} \mathrm{SO}_{4}$ (7:3) for $2 \mathrm{~h}$ under continuous stirring. The treated membranes were then washed with de-ionized water until a neutral $\mathrm{pH}$ was obtained. They were then kept in an oven at a constant temperature of $60^{\circ} \mathrm{C} .{ }^{35}$

WU, SR, MU, IEC, methanol permeability and proton conductivity WU, SR and MU analyses were performed by utilizing cut vacuum-dried pieces of different membrane samples having areas of $2 \times 2 \mathrm{~cm}^{2}$. The dried pieces were first weighed, and then their thicknesses were measured. They were then immersed in de-ionized water/aqueous methanol solution for $24 \mathrm{~h}$. The wet pieces were then taken out, wiped to remove unabsorbed water/aqueous methanol solution and subjected to weighing and thickness measurements. The WU and the SR of the membrane samples were measured at four different temperatures, that is, 20, 40, 60 and $80^{\circ} \mathrm{C}$. For the determination of $\mathrm{MU}$ capacities of the membrane samples, four different molar concentrations (that is, 2, 4, 6 and $8 \mathrm{M}$ ) of methanol in water were used. Liquid uptakes (that is, WU and MU) and SRs were measured (in percentage (\%)) using Equations (1) and (2).

$$
\text { Liquid uptake }(\%)=\left(W_{\text {wet }}-W_{\text {dry }}\right) \times 100 / W_{\text {dry }}
$$

where $W_{\text {dry }}$ and $W_{\text {wet }}$ represent the weights of the dry and wet membrane samples, respectively.

The swelling ratio was calculated both in terms of changes in the thicknesses and areas of the membranes.

In terms of change in thickness:

$$
\operatorname{SR}(\%)=\left(T_{\text {wet }}-T_{\text {dry }}\right) \times 100 / T_{\text {dry }}
$$

where $T_{\text {dry }}$ and $T_{\text {wet }}$ represent the thicknesses of the dry and wet membrane samples, respectively.

In terms of change in area:

$$
\operatorname{SR}(\%)=\left(A_{\text {wet }}-A_{\text {dry }}\right) \times 100 / A_{\text {dry }}
$$

where $A_{\text {dry }}$ and $A_{\text {wet }}$ represent the areas of the dry and wet membrane samples, respectively.

The IECs of the membranes were determined by employing the conventional titration technique. ${ }^{26-32}$ In this method, $2 \times 2 \mathrm{~cm}^{2}$ pieces of each membrane were soaked in a large volume of $1 \mathrm{M} \mathrm{H}_{2} \mathrm{SO}_{4}$ solution for $24 \mathrm{~h}$. This was followed by repeated washing of the membrane samples with distilled water to remove excess $\mathrm{H}_{2} \mathrm{SO}_{4}$. The samples were then placed in $1 \mathrm{M} \mathrm{NaCl}$ solution $(50 \mathrm{ml})$, heated to $40{ }^{\circ} \mathrm{C}$ and equilibrated for $24 \mathrm{~h}$ to replace the protons with sodium $\left(\mathrm{Na}^{+}\right)$ions. Finally, the remaining solutions were titrated with aqueous $\mathrm{NaOH}$ solution $(0.01 \mathrm{~N})$, using a phenolphthalein indicator. The experimentally determined IEC values (in meqg ${ }^{-1}$ ) were calculated using the following equation:

$$
(\mathrm{IEC})_{\mathrm{m}}=V_{\mathrm{NaOH}} \times S_{\mathrm{NaOH}} / W_{\mathrm{dry}}
$$

where (IEC) $)_{\mathrm{m}}$ is the experimentally measured IEC value and $\mathrm{V}_{\mathrm{NaOH}}$ and $\mathrm{S}_{\mathrm{NaOH}}$ are, respectively, the volume and strength of the $\mathrm{NaOH}$ solution used in the titration.

The theoretical IEC values of the individual components of the blend membranes were calculated from their respective percentage of degree of sulfonation (\%DS) values using the following equation ${ }^{36,37}$ :

For SPVdF,

$$
\left(\mathrm{IEC}_{1}\right)_{\mathrm{cal}}=\mathrm{DS}_{1} \times 1000 /\left(M_{1}+81 \times \mathrm{DS}_{1}\right)
$$

For SPAni,

$$
\left(\mathrm{IEC}_{2}\right)_{\text {cal }}=\mathrm{DS}_{2} \times 1000 /\left(M_{2}+81 \times \mathrm{DS}_{2}\right)
$$

The theoretical IEC values of the different blend membranes were calculated from the IEC values of the individual components using the following equation:

$$
(\mathrm{IEC})_{\mathrm{cal}}=\left[\left(\mathrm{IEC}_{1}\right)_{\mathrm{cal}} \times W_{1}+\left(\mathrm{IEC}_{2}\right)_{\mathrm{cal}} \times W_{2}\right] / 100
$$

where the subscript ' 1 ' represents the SPVdF component, the subscript ' 2 ' stands for the SPAni component, $M$ is the molecular weight of the repeating unit of the respective polymer, 81 is the molecular weight of the $-\mathrm{SO}_{3} \mathrm{H}$ group and $W$ stands for the $\mathrm{wt} \%$ of the respective polymer within the blend.

Methanol permeability analyses were carried out using four different molar concentrations of methanol in aqueous solutions, that is, 2, 4, 6 and $8 \mathrm{M}$. A conventional two-compartment glass diffusion cell was used for this purpose, where compartment ' $a$ ' was filled with the aqueous methanol solutions and compartment ' $b$ ' was filled with pure water. ${ }^{26} \mathrm{SNP}$ (that is, a mixture of sodium nitroprusside ( $5 \mathrm{~g}$ in $50 \mathrm{ml}$ water), potassium ferrocyanide ( $5 \mathrm{~g}$ in $50 \mathrm{ml}$ water) and $\mathrm{NaOH}$ (2.5 g in $50 \mathrm{ml}$ water) prepared at $4{ }^{\circ} \mathrm{C}$ ) was utilized as the chromogenic reagent. The methanol permeability values, as determined by the UV-Vis spectroscopic method, were calculated by employing the following equation: ${ }^{29}$

$$
-\ln \left(1-2 C_{\mathrm{b}} / C_{\mathrm{a}}\right)=2 A D K\left(t-t_{0}\right) / l V_{\mathrm{b}}
$$

where $C_{\mathrm{a}}$ and $C_{\mathrm{b}}$ are concentrations of aqueous methanol solutions in compartments a and b, respectively; $D, K$ and DK represent the methanol diffusivity, partition coefficient and permeability of the membrane, respectively; $A$ is the area of the membrane available for methanol permeation; $l$ is the thickness of the membrane; $t_{0}$ and $t$ represent, respectively, the initial time and 
the times when aliquots were withdrawn for analysis; and $V_{\mathrm{b}}$ is the volume of compartment 'b'.

The proton conductivity $(\sigma)$ values of the membranes were calculated from their respective impedance results by employing the following relation:

$$
\sigma=T / R A
$$

where $T$ and $A$ represent the thickness and the cross-sectional area of the membrane sample and $R$ is the resistance derived from the low intersect of the high frequency semi-circle on a complex impedance plane with the real $\left(Z^{\prime}\right)$ axis.

\section{RESULTS AND DISCUSSION}

\section{FT-IR analysis and determination of the DS}

The structural identities of the SPVdF granules were characterized by employing FT-IR spectroscopy (Figure 1). The peak obtained at $1161 \mathrm{~cm}^{-1}$ has been assigned to the symmetric stretching of the constituent $\mathrm{S}=\mathrm{O}$ bonds of the sulfonic acid group, and the sharp peak obtained at $1399 \mathrm{~cm}^{-1}$ is due to the asymmetric stretching of the $\mathrm{S}=\mathrm{O}$ bonds. The peak at $3743 \mathrm{~cm}^{-1}$ corresponds to the stretching of $\mathrm{O}-\mathrm{H}$ bonds present in the $-\mathrm{SO}_{3} \mathrm{H}$ groups. The new absorption peak that appeared at $1161 \mathrm{~cm}^{-1}$ for the SPVdF granules confirms the successful introduction of $-\mathrm{SO}_{3} \mathrm{H}$ groups to the polymer structure. ${ }^{32}$ The area of this particular peak was calculated for the SPVdF sample (X) and compared with the area obtained for the pure PVdF sample (Y). From the ratio $\mathrm{X}: \mathrm{Y}$, the \%DS of the SPVdF granules was calculated to be approximately $22 \%$. It should be noted that sulfonation of PVdF beyond 22\% DS led to deterioration of the mechanical strength of the polymer.

The SPAni used in this work possessed a \%DS value of approximately $29 \%$. The FT-IR spectra of pure and partially sulfonated PAni is presented in Supplementary Figure S1. ${ }^{28}$

\section{Determination of percentage of crystallinity and inter-chain separation of SPVdF}

From the XRD patterns of pure and partially sulfonated PVdF, as shown in Figure 2, it can be observed that upon the introduction of $\mathrm{SO}_{3} \mathrm{H}$ groups, the crystallinity of PVdF decreases. The \%crystallinity of the pure and the partially sulfonated PVdF samples was calculated using the following equation:

$$
\% \text { Crystallinity }=\left(A_{\mathrm{c}} \times 100\right) / A_{\mathrm{t}}
$$

where $A_{\mathrm{c}}$ and $A_{\mathrm{t}}$ represent the area of the crystalline regions and the total area under the peak, respectively.

It was found that, whereas pure PVdF possessed a \%crystallinity value of 35.7, SPVdF exhibited a decreased \%crystallinity value of 31.5. A closer look at the spectra reveals that pure PVdF exhibited amorphous peaks in the region of $13.92-20.11^{\circ}$, with a corresponding

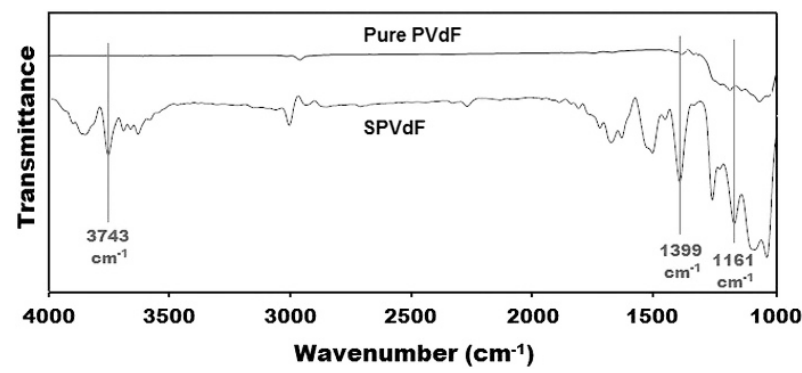

Figure 1 FT-IR spectra of PVdF and SPVdF corresponding to a reaction temperature of $50^{\circ} \mathrm{C}$ and a reaction duration of $2 \mathrm{~h}$. A full color version of this figure is available at the Polymer Journal online. peak of $17.81^{\circ}$; however, for SPVdF, the peak shifted toward slightly higher values of $2 \theta$ (that is, $18.06^{\circ}$ ), with an accompanying decrease in peak intensity. On a similar note, the inter-chain separation $(R)$ values were calculated for the PVdF and SPVdF samples from the following equation, which revealed that, whereas the former possessed an $\mathrm{R}$ value of $0.210 \mathrm{~nm}$, the latter exhibited a slightly increased $R$ value of $0.215 \mathrm{~nm}^{32}$

$$
R=5 \lambda / 8 \sin \theta
$$

where $\lambda$ is the wavelength, and $\theta$ is the Bragg angle.

The XRD spectra of PAni and SPAni are presented in Supplementary Figure S2. ${ }^{28}$ In addition, the \%crystallinity and the inter-chain separation values of PAni and SPAni are presented in Supplementary Table $\mathrm{S} 1 .^{28}$

\section{Analysis of the \%WUs and the \%SRs of the membranes}

The WU behavior of a polymer is a function of its hydrophilicity/ hydrophobicity, and this property is often correlated with the proton conductivity of that polymer. ${ }^{38,39}$ Again, swellability of a polymer in water is directly proportional to its \%WU capacity. PVdF is a hydrophobic polymer ${ }^{27,40-43}$ - a property that is reflected in its extremely low \%WU capacity and \%SR (Figures 3 and 4). The introduction of hydrophilic $-\mathrm{SO}_{3} \mathrm{H}$ groups within the chemical structure of PVdF induced an enhancement of its \%WU capacity and \%SR. Further increments in these two properties were brought about by the incorporation of SPAni (DS: approximately 29\%) within the SPVdF polymer (DS: approximately $22 \%$ ), which yielded SPVdF/ SPAni blends. PAni (in its emeraldine salt form) possesses a hydrophilic character, ${ }^{44-47}$ which is further increased upon the introduction of hydrophilic $-\mathrm{SO}_{3} \mathrm{H}$ groups within its chemical structure ${ }^{48,49}$ therefore, the $\% \mathrm{WU}$ and $\% \mathrm{SR}$ values of the SPVdF/ SPAni blend increased with increasing wt $\%$ of the incorporated SPAni (Figures 3 and 4). These SPAni-induced enhancements of the \%WU and \%SR values of the polymer electrolyte membranes (PEMs) have also been reported for sulfonated SPVdF copolymer/SPAni and Nafion/SPAni membranes. ${ }^{28-30}$ It can also be seen from Figure 4 that the \%SRs, both in terms of the change in the thickness (Figure $4 \mathrm{a}$ ) and the area (Figure $4 \mathrm{~b}$ ) of the membrane samples, followed the same trend as expected.

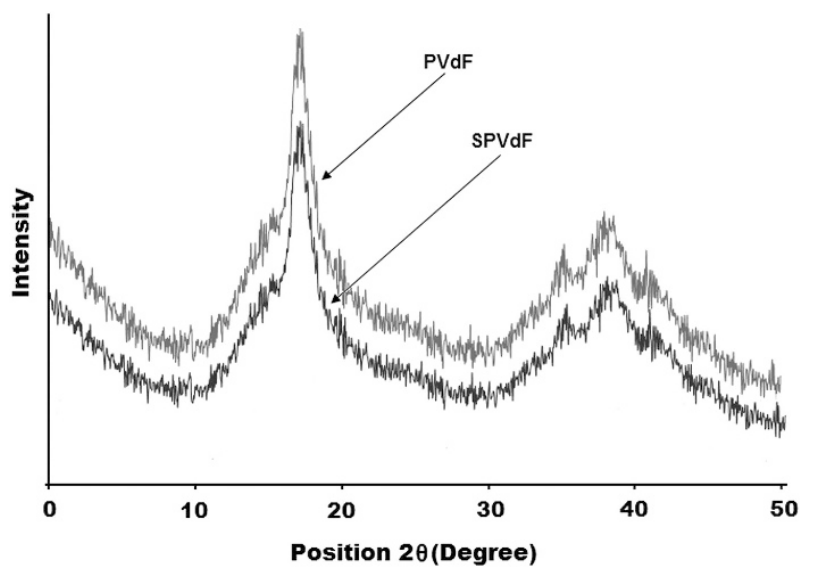

Figure $2 \mathrm{XRD}$ spectra of $\mathrm{PVdF}$ and $\mathrm{SPVdF}$ obtained at a reaction temperature of $50{ }^{\circ} \mathrm{C}$ for a reaction duration of $2 \mathrm{~h} .{ }^{32} \mathrm{~A}$ full color version of this figure is available at the Polymer Journal online. 
Analysis of the IECs and the proton conductivities of the membranes

IEC is a function of the number of available ion-exchange sites present within the membrane structure. Within the SPVdF/SPAni blend membrane, the presence of $-\mathrm{SO}_{3} \mathrm{H}$ groups in both SPVdF and SPAni and lone pair of electrons on $\mathrm{N}$-atoms, which are present in each repeating unit of SPAni, contribute to its proton exchange capacity. ${ }^{50}$ As a result, the blend membranes exhibited higher exchange capacities compared with the pristine PVdF (having negligible IEC) and SPVdF (that is, $0.15 \mathrm{meq} \mathrm{g}^{-1}$ ) membranes. Because the SPAni component possesses a higher DS (compared with SPVdF), as well as a lone pair of electrons, the IEC of the blend membrane was found to increase with increasing SPAni content up to a value of $0.31 \mathrm{meqg}^{-1}$ for the SPVdF/SPAni (80/20) blend membrane (Figure 5). The calculated IEC values of the blend membranes are also presented in Figure 5. It can be seen from the figure that the experimentally determined IEC value for the pristine SPVdF membrane agrees satisfactorily with the theoretically calculated value. However, with the incorporation and subsequent increase in the content of SPAni within the blend membrane, the $(\text { IEC })_{m}$ values of the membranes increased above those of the (IEC) cal values. These increases are due to the contribution of the lone pair of electrons on the $\mathrm{N}$-atoms present in each repeating unit of SPAni to the IEC of the blend membranes.

Although the pristine Nafion-117 membrane exhibits a high enough IEC value, 0.8 meq g $^{-1}, 26$ membranes based on pure PVdF and its copolymer are known to produce lower IEC values, even in the presence of Nafion as a co-constituent. For example, an IEC value of $0.21 \mathrm{meq} \mathrm{g}^{-1}$ has been reported for a PVdF/Nafion $(70 / 30 \mathrm{w} / \mathrm{w})$ blend membrane. ${ }^{32}$ Again, it has been reported that, whereas the pure PVdF copolymer exhibited a negligible IEC value, a $31 \%$ sulfonated PVdF copolymer membrane produced an IEC value of $0.42 \mathrm{meqg}^{-1} \cdot{ }^{27}$ However, in our earlier works, the incorporation of SPAni was shown to increase the IEC values of the blend and coated membranes with a sulfonated PVdF copolymer and Nafion as co-constituents. ${ }^{28-30}$ The same trend was also followed in this work, as the incorporation of SPAni induced an enhancement in the IEC values of the blend membranes constituting SPVdF as a co-constituent.

With the objective of achieving a high IEC value to obtain a membrane with high proton conductivity, Nafion was introduced within the SPVdF/SPAni blend membrane. It was pleasing to observe

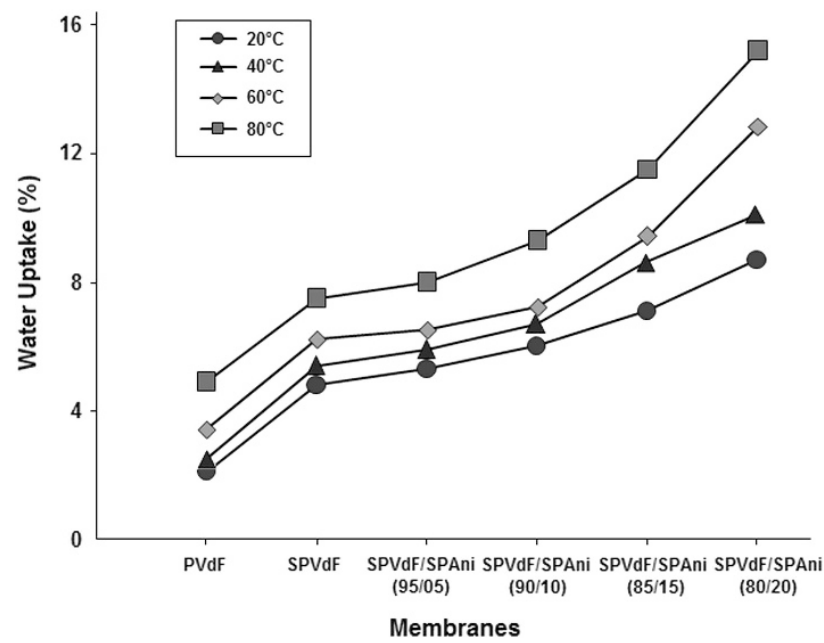

Figure $3 \%$ WUs of the membranes at $20,40,60$ and $80^{\circ} \mathrm{C}$. A full color version of this figure is available at the Polymer Journal online.
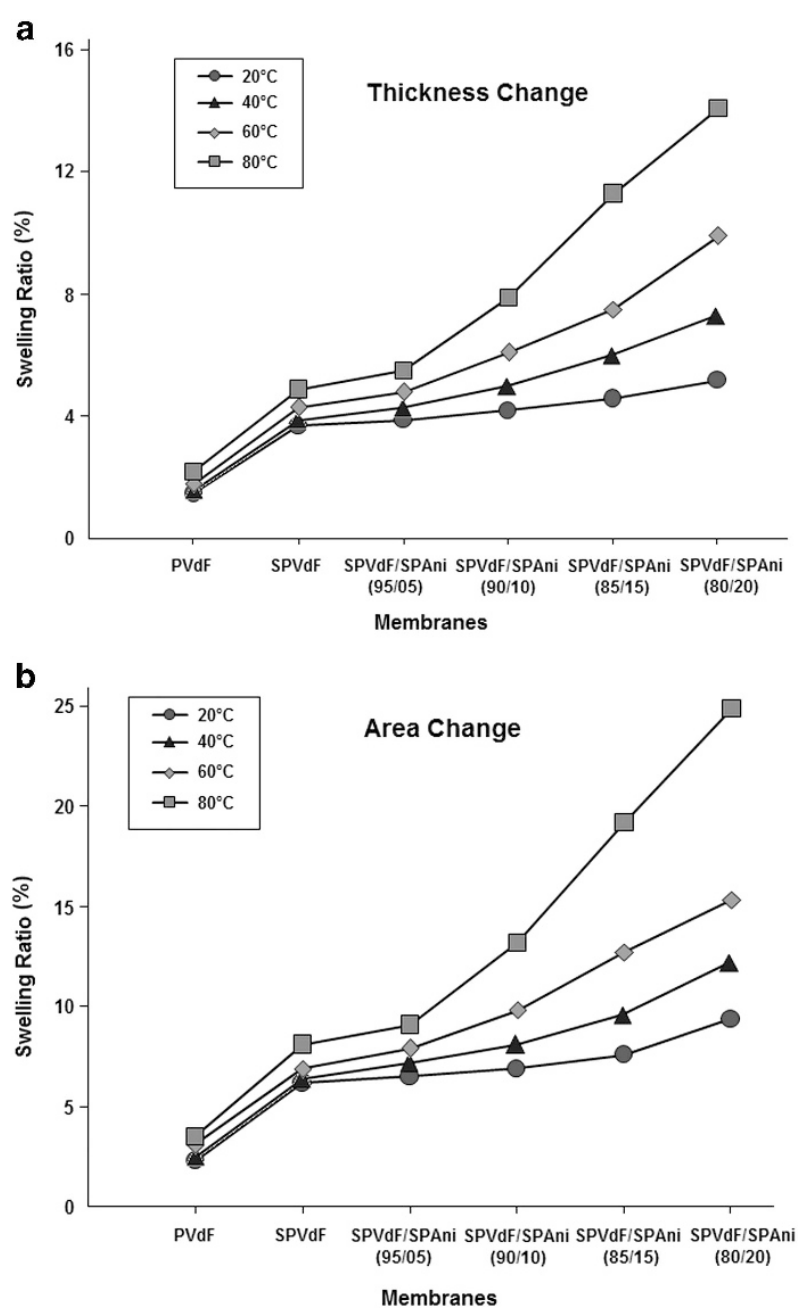

Figure $4 \%$ SRs of the membranes at $20,40,60$ and $80^{\circ} \mathrm{C}$ : (a) in terms of thickness change and (b) in terms of area change. A full color version of this figure is available at the Polymer Journal online.

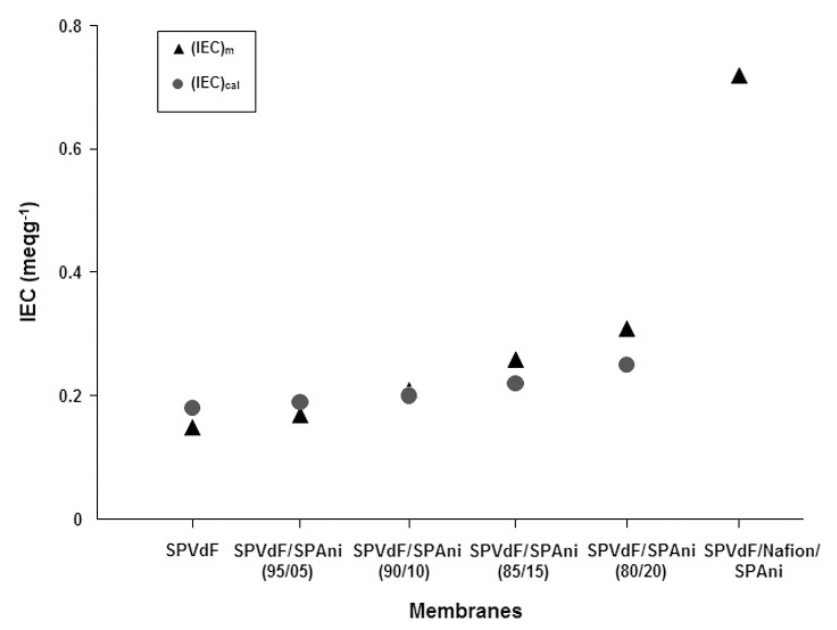

Figure 5 Measured and calculated IEC values of the different membranes at $20^{\circ} \mathrm{C}$. A full color version of this figure is available at the Polymer Journal online. 
that the resulting ternary blend membrane, with a constituent wt $\%$ ratio of SPVdF:Nafion:SPAni $=50: 30: 20$, exhibited a drastically improved IEC value of $0.72 \mathrm{meq}^{-1}$ (Figure 5). This drastic improvement in IEC can be attributed to the co-presence of Nafion and SPAni and can be correlated with the previously obtained high IEC values for the Nafion/SPAni blend membranes. ${ }^{30}$

The proton-conducting ability of a membrane, in most instances, depends on its IEC because the factors that determine the latter often contribute to the former. ${ }^{51}$ The proton conductivity results plotted in Figure 6 convey the abovementioned justification. Whereas the pristine PVdF membrane produced a negligible proton conductivity value, the incorporation of $-\mathrm{SO}_{3} \mathrm{H}$ groups led to an enhanced conductivity value of $1.2 \times 10^{-3} \mathrm{~S} \mathrm{~cm}^{-1}$. Again, the introduction of SPAni to SPVdF resulted in a further increase of the conductivity value up to $4.9 \times 10^{-3} \mathrm{~S} \mathrm{~cm}^{-1}$ for the SPVdF/SPAni (80/20) blend membrane.

As mentioned above for the IECs, the proton conductivity values reported for pure PVdF and its copolymer were significantly lower than that of pristine Nafion- 117 (that is, $3 \times 10^{-2} \mathrm{~S} \mathrm{~cm}^{-1}$ ). Das et al. ${ }^{27}$ reported a proton conductivity value of $3.75 \times 10^{-3} \mathrm{~S} \mathrm{~cm}^{-1}$ for a $31 \%$ sulfonated PVdF copolymer membrane. Cho et al. ${ }^{52}$ obtained a conductivity value of $9.8 \times 10^{-6} \mathrm{~S} \mathrm{~cm}^{-1}$ for a $\mathrm{PVdF}$ copolymer/Nafion $(80 / 20 \mathrm{w} / \mathrm{w})$ blend membrane. Kumar et al. ${ }^{12}$ reported a conductivity value of $1 \times 10^{-3} \mathrm{~S} \mathrm{~cm}^{-1}$ for a PVdF copolymer/Nafion/AlO $(\mathrm{OH})$ (51 wt\%: 41 wt $\%: 8$ wt $\%$ ) composite membrane. Similarly, a compatibilized styrene-(ethylene-butylene)-styrene block copolymer/ $\mathrm{PVdF}$ blend membrane produced a proton conductivity value of $5.5 \times 10^{-3} \mathrm{~S} \mathrm{~cm}^{-1} .19$ Likewise, a PVdF copolymer/recast Nafion $(80 / 20 \mathrm{w} / \mathrm{w})$ blend membrane exhibited a conductivity value of $5.5 \times 10^{-3} \mathrm{~S} \mathrm{~cm}^{-1} .{ }^{10}$ However, the incorporation of SPAni with pure and partially sulfonated PVdF copolymers has been shown to increase the proton conductivity values of the resulting membranes over those of the pristine membranes. ${ }^{28-30}$ For example, a sulfonated PVdF copolymer/SPAni $(60 / 40 \mathrm{w} / \mathrm{w})$ blend membrane produced a proton conductivity value of $6.78 \times 10^{-3} \mathrm{~S} \mathrm{~cm}^{-1}$, which contrasted the value of $3.75 \times 10^{-3} \mathrm{~S} \mathrm{~cm}^{-1}$ observed for the pristine sulfonated $\mathrm{PVdF}$ copolymer membrane. ${ }^{28}$ Following the same trend, this work also indicated that the presence of SPAni induced increased proton conductivity in the SPVdF/SPAni blend membranes.

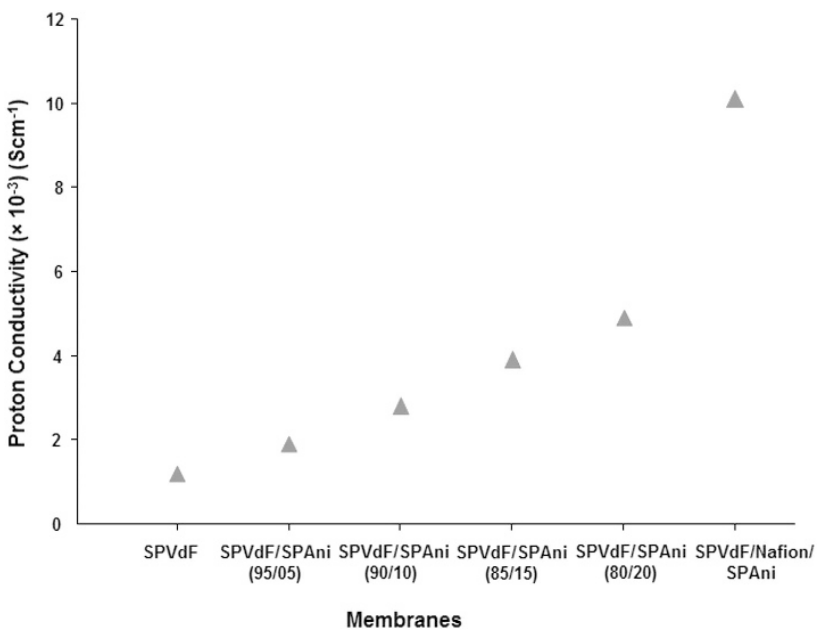

Figure 6 Proton conductivities of the different membranes at $20^{\circ} \mathrm{C}$. A full color version of this figure is available at the Polymer Journal online.
Furthermore, as was observed for the IEC analysis, the SPVdF/ Nafion/SPAni (50:30:20) ternary blend membrane exhibited a much improved proton conductivity value of $1.01 \times 10^{-2} \mathrm{~S} \mathrm{~cm}^{-1}$ (Figure 6). This obtained result was comparable with the conductivity values of the pristine Nafion-117 membrane (that is, $3 \times 10^{-2} \mathrm{~S} \mathrm{~cm}^{-1}$ ) and the SPVdF/Nafion $(70 / 30 \mathrm{w} / \mathrm{w})$ blend membrane (that is, $\left.\sim 1.7 \times 10^{-2} \mathrm{~S} \mathrm{~cm}^{-1}\right) .^{32}$

\section{Analysis of the \%MUs and the methanol permeabilities of the membranes}

The \%MU capacity of a polymeric membrane in an aqueous methanol solution depends on its affinity for both water and methanol, ${ }^{53}$ as well as on the space present within the membrane structure available for liquid uptake. As expected, the pristine PVdF exhibited the lowest \% MU value among the membranes studied in this work by virtue of it possessing both hydrophobic and methanophobic characteristics (Figure 7). ${ }^{40}$ However, the pristine SPVdF membrane showed a considerably enhanced \%MU capacity owing to the presence of hydrophilic and methanophilic $-\mathrm{SO}_{3} \mathrm{H}$ groups within the chemical structure of PVdF. The effect of available space within the membrane structure on the \%MU capacity was realized upon incorporation of SPAni into SPVdF. Although SPAni is more hydrophilic than SPVdF, its ability to block pores and methanol channels present within the base SPVdF polymer resulted in a reduction of the space available within SPVdF. ${ }^{7,28-31,54}$ As a result, the \%MU value of the blend membrane progressively decreased with increasing SPAni content (Figure 7). This observation is similar to that observed for Nafion/ SPAni and sulfonated PVdF copolymer/SPAni blend membranes. ${ }^{28,30}$ However, the SPVdF/Nafion/SPAni (50:30:20) ternary blend membrane produced increased \%MU values at all studied methanol concentrations compared with those obtained for the SPVdF/SPAni (80:20) binary blend membrane owing to the presence of Nafion, which is known to possess a high affinity for methanol. ${ }^{28,30,55}$

Using the same justification for the observed \%MU results, the methanol permeability values presented in Table 1 can be explained. It can be clearly observed from the table that the trend obtained for the $\% \mathrm{MU}$ capacity of the different membranes studied is similar to the trend observed for their methanol permeability values. In addition, the phenomenon of methanol permeability involves the movement of molecules across the membrane thickness; therefore, the size of the transported molecules should also be considered when analyzing the methanol permeability results. Methanol, being larger than water, is

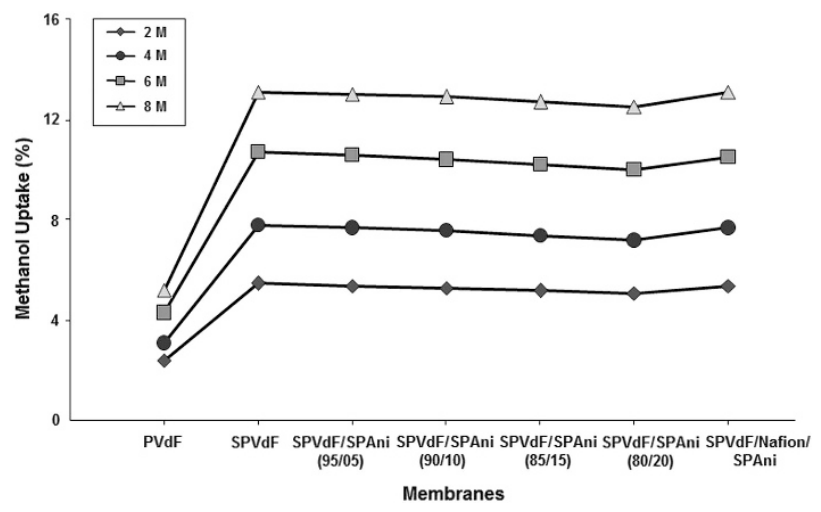

Figure $7 \%$ MUs of the membranes at concentrations of $2,4,6$ and $8 \mathrm{~m}$ aqueous methanol. A full color version of this figure is available at the Polymer Journal online. 
more prone to obstruction by space constraints within the membrane structure compared with water molecules. Another factor that determines the methanol permeability of a membrane is the methanol affinity of its constituent materials. In this regard, SPVdF and its copolymer, as indicated by their \%MU capacities, are known to possess very low methanol affinity. ${ }^{28-30,32}$ These two factors contributed to the very low methanol permeability values of the studied blend membranes. Therefore, although the \%WU of the PEMs increased with increasing SPAni content, both the \%MU and the methanol permeability values of the PEMs decreased with increasing amounts of SPAni. Similar results have also been reported previously for Nafion/SPAni blend and SPVdF copolymer/SPAni blend and coated membranes. ${ }^{28-30}$ For example, a Nafion/SPAni $(70 / 30 \mathrm{w} / \mathrm{w})$ blend membrane exhibited a permeability value of $9.12 \times 10^{-8} \mathrm{~cm}^{2} \mathrm{~s}^{-1}$, which was significantly lower than the value of $1.22 \times 10^{-6} \mathrm{~cm}^{2} \mathrm{~s}^{-1}$ observed for pristine Nafion-117. ${ }^{30}$ Similarly, a sulfonated PVdF copolymer/SPAni $(60 / 40 \mathrm{w} / \mathrm{w})$ blend membrane exhibited a lower permeability value of $1.16 \times 10^{-8} \mathrm{~cm}^{2} \mathrm{~s}^{-1}$ compared with the value of $2.51 \times 10^{-7} \mathrm{~cm}^{2} \mathrm{~s}^{-1}$ produced by a pristine sulfonated PVdF copolymer. ${ }^{28}$ However, the ternary blend membrane exhibited increased methanol permeability values compared with those obtained for the SPVdF/SPAni (80/20) binary blend membrane for all studied methanol concentrations, which was due to the presence of Nafion within the blend. ${ }^{28,30,55}$ Scanning electron microscopic images

Table 1 Methanol permeability values of the different membranes at methanol concentrations of $2,4,6$ and $8 \mathrm{M}$ and $20^{\circ} \mathrm{C}$

\begin{tabular}{|c|c|c|c|c|c|c|c|c|}
\hline \multirow[b]{2}{*}{ Membrane compositions } & \multicolumn{4}{|c|}{ Methanol permeability $\left(\mathrm{cm}^{2} \mathrm{~s}^{-1}\right)$} & \multicolumn{4}{|c|}{ Methanol permeability after $48 \mathrm{~h}$ treatment $\left(\mathrm{cm}^{2} \mathrm{~s}^{-1}\right)$} \\
\hline & $2 M$ & $4 M$ & $6 M$ & $8 M$ & $2 M$ & $4 M$ & $6 M$ & $8 M$ \\
\hline Pristine PVdF & $1.60 \times 10^{-10}$ & $3.20 \times 10^{-10}$ & $8.91 \times 10^{-10}$ & $2.59 \times 10^{-9}$ & $4.01 \times 10^{-10}$ & $5.98 \times 10^{-10}$ & $1.12 \times 10^{-9}$ & $6.39 \times 10^{-9}$ \\
\hline Pristine SPVdF & $8.11 \times 10^{-9}$ & $1.50 \times 10^{-8}$ & $3.19 \times 10^{-8}$ & $4.90 \times 10^{-8}$ & $2.23 \times 10^{-8}$ & $5.49 \times 10^{-8}$ & $7.23 \times 10^{-8}$ & $9.79 \times 10^{-8}$ \\
\hline SPVdF/SPAni (95/05) blend & $7.60 \times 10^{-9}$ & $9.21 \times 10^{-9}$ & $1.70 \times 10^{-8}$ & $3.09 \times 10^{-8}$ & $1.10 \times 10^{-8}$ & $3.89 \times 10^{-8}$ & $6.45 \times 10^{-8}$ & $9.23 \times 10^{-8}$ \\
\hline SPVdF/SPAni (90/10) blend & $6.21 \times 10^{-9}$ & $7.39 \times 10^{-9}$ & $9.90 \times 10^{-9}$ & $1.52 \times 10^{-8}$ & $9.66 \times 10^{-9}$ & $1.19 \times 10^{-8}$ & $5.48 \times 10^{-8}$ & $7.67 \times 10^{-8}$ \\
\hline SPVdF/SPAni (85/15) blend & $4.28 \times 10^{-9}$ & $5.21 \times 10^{-9}$ & $7.49 \times 10^{-9}$ & $9.70 \times 10^{-9}$ & $7.79 \times 10^{-9}$ & $9.09 \times 10^{-9}$ & $2.58 \times 10^{-8}$ & $5.86 \times 10^{-8}$ \\
\hline SPVdF/SPAni (80/20) blend & $1.50 \times 10^{-9}$ & $3.11 \times 10^{-9}$ & $4.89 \times 10^{-9}$ & $6.30 \times 10^{-9}$ & $5.62 \times 10^{-9}$ & $7.58 \times 10^{-9}$ & $1.27 \times 10^{-8}$ & $3.90 \times 10^{-8}$ \\
\hline SPVdF/Nafion/SPAni ternary blend & $6.99 \times 10^{-9}$ & $8.65 \times 10^{-9}$ & $1.26 \times 10^{-8}$ & $3.57 \times 10^{-8}$ & $1.33 \times 10^{-8}$ & $3.24 \times 10^{-8}$ & $6.39 \times 10^{-8}$ & $1.56 \times 10^{-7}$ \\
\hline
\end{tabular}

Abbreviations: SPAni, partially sulfonated polyaniline; SPVdF, partially sulfonated poly(vinylidene fluoride).
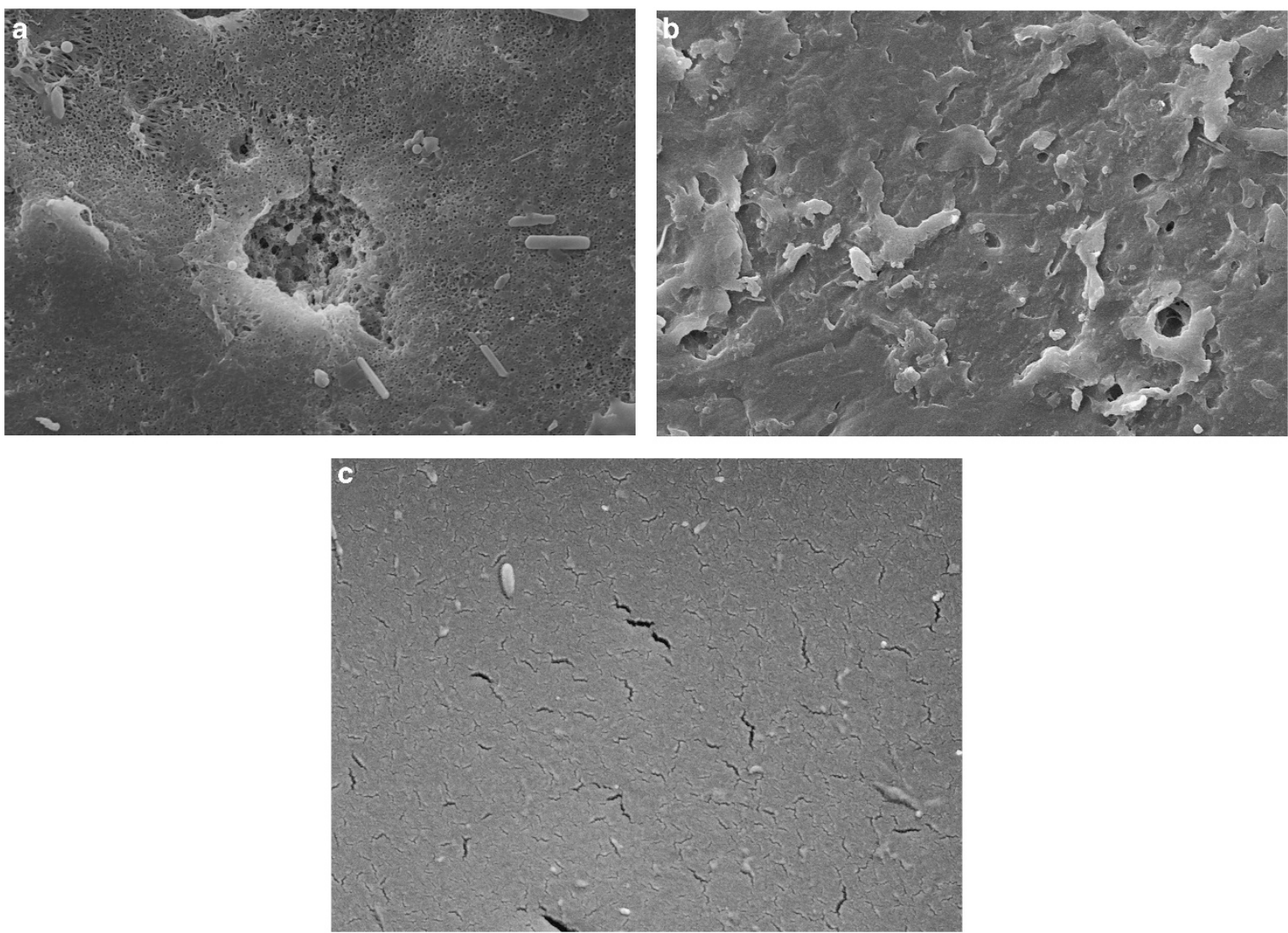

Figure 8 SEM images of (a) the pristine SPVdF, (b) the SPVdF/SPAni (80/20) binary blend and (c) the SPVdF/Nafion/SPAni (50:30:20) ternary blend membranes (magnification: $\times 5000$ ). 
of the pristine SPVdF, the SPVdF/SPAni (80/20) binary blend and the SPVdF/Nafion/SPAni ternary blend membranes studied in this work are presented in Figure 8 . The micrographs clearly reveal that the pristine SPVdF membrane contains a larger number of pores than the binary blend membrane. However, the ternary blend membrane displayed few pores owing to the presence of Nafion. The cumulative effect of all of these factors led to the results presented in Table 1.

Methanol permeability analyses were also conducted on PEMs that were kept immersed in aqueous methanol solutions for $48 \mathrm{~h}$ prior to analyses. The obtained results are presented in Table 1 . It can be observed that the permeability values of the PEMs after this treatment were increased compared with the earlier sample PEMs. However, the trend observed for both sets of PEMs was similar, that is, the PEMs exhibited decreased methanol permeability values with increasing SPAni content. Similarly, the treated ternary blend membrane produced increased methanol permeability values compared with those obtained for the SPVdF/SPAni (80/20) binary blend membrane at all studied methanol concentrations.

Determination of the selectivity ratios of the membranes

The extent to which a membrane is able to suppress the flow of methanol across its thickness while allowing the conduction of protons determines its selectivity potential. In other words, the membrane selectivity ratio is the ratio of proton conductivity to methanol permeability exhibited by a membrane. Composite membranes, which consist of a proton conductive dispersed phase and a methanophobic continuous phase, often exhibit high membrane selectivity ratios. ${ }^{4,28-31,54}$ The blend membranes studied in this work also consisted of a proton conductive SPAni phase and a methanophobic $\mathrm{PVdF}$ phase (having proton conductive $-\mathrm{SO}_{3} \mathrm{H}$ groups). As a result, membrane selectivity ratios as high as $3.27 \times 10^{6} \mathrm{Ss} \mathrm{cm}^{-3}$ (while using a $2 \mathrm{M}$ aqueous methanol solution) and $7.78 \times 10^{5} \mathrm{Ss} \mathrm{cm}^{-3}$ (while using an $8 \mathrm{M}$ aqueous methanol solution) were obtained with the SPVdF/ SPAni (80/20) blend membrane (Table 2). In addition, this particular blend membrane exhibited higher selectivity ratios compared with the pristine SPVdF membrane at all studied methanol concentrations (Table 2). Moreover, it can be observed from the table that the selectivity ratio of the blend membranes increased with increasing SPAni content, which is attributed to the increase in proton conductivity along with the simultaneous decrease in methanol permeability. In the case of the ternary blend membrane, the selectivity ratio values were found to decrease from the SPVdF/SPAni $(80 / 20)$ blend membrane at all methanol concentrations studied. This result is due to the higher methanol permeability values exhibited by the ternary blend membrane compared with the SPVdF/SPAni $(80 / 20)$ binary blend membrane. However, the selectivity values exhibited by the ternary blend membrane were found to be higher than the pristine SPVdF membrane at all methanol concentrations studied.

Furthermore, the selectivity ratios for the PEMs that were kept immersed in the aqueous methanol solutions for $48 \mathrm{~h}$ prior to analysis also exhibited a similar trend (that is, an increasing selectivity ratio with increasing SPAni content) (Table 2). Similarly, as observed above, the ternary blend membrane exhibited lower selectivity values at all methanol concentrations studied compared with the SPVdF/SPAni (80/20) binary blend membrane.

\section{Analysis of the tensile strengths of the membranes}

The mechanical integrity of the proposed blend membranes was determined by a tensile strength analysis. The results obtained are plotted in Figure 9. It was found that the blend membranes exhibited lower tensile strengths compared with both the pristine PVdF (that is, $12.32 \mathrm{MPa}$ ) and the SPVdF (that is, $9.96 \mathrm{MPa}$ ) membranes. This is due to the incorporation of SPAni, which is known to possess low mechanical strength. ${ }^{28-30}$ As a result, the tensile strength of the blend membrane was found to decrease with increasing SPAni content. Nevertheless, the tensile strength exhibited by the SPVdF/SPAni $(80 / 20)$ blend membrane (that is, $9.01 \mathrm{MPa}$ ) was satisfactory considering its potential applications in devices, such as fuel cells. However, the tensile strength exhibited by the ternary blend membrane (that is, $10.54 \mathrm{MPa}$ ) was found to be higher than that exhibited by the pristine SPVdF membrane (Figure 9), which was the result of the presence of Nafion within the blend membrane.

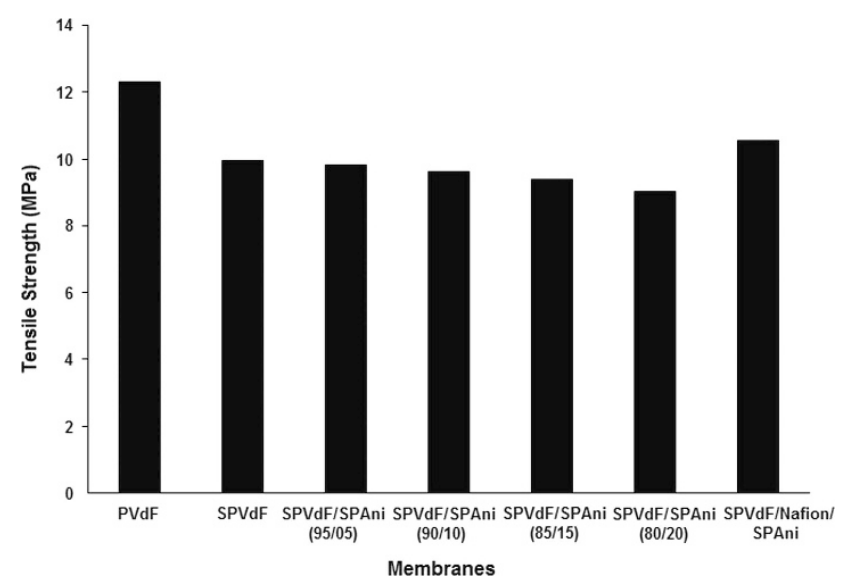

Figure 9 Tensile strengths of the different membranes at $20^{\circ} \mathrm{C}$.

Table 2 Selectivity ratios of the different membranes at methanol concentrations 2, 4, 6 and $8 \mathrm{~m}$ and $20^{\circ} \mathrm{C}$

\begin{tabular}{|c|c|c|c|c|c|c|c|c|}
\hline \multirow[b]{2}{*}{ Membrane compositions } & \multicolumn{4}{|c|}{ Membrane selectivity ratios $\left(\mathrm{Ss} \mathrm{cm}^{-3}\right.$ ) } & \multicolumn{4}{|c|}{ Membrane selectivity ratios after $48 \mathrm{~h}$ treatment $\left(\mathrm{Ss} \mathrm{cm}^{-3}\right)$} \\
\hline & $2 M$ & $4 M$ & $6 M$ & $8 M$ & $2 M$ & $4 M$ & $6 M$ & $8 M$ \\
\hline Pristine SPVdF & $1.48 \times 10^{5}$ & $8.01 \times 10^{4}$ & $3.75 \times 10^{4}$ & $2.45 \times 10^{4}$ & $5.38 \times 10^{4}$ & $2.19 \times 10^{4}$ & $1.66 \times 10^{4}$ & $1.23 \times 10^{4}$ \\
\hline SPVdF/SPAni (95/05) blend & $2.50 \times 10^{5}$ & $2.06 \times 10^{5}$ & $1.12 \times 10^{5}$ & $6.15 \times 10^{4}$ & $1.73 \times 10^{5}$ & $4.88 \times 10^{4}$ & $2.95 \times 10^{4}$ & $2.06 \times 10^{4}$ \\
\hline SPVdF/SPAni (90/10) blend & $4.51 \times 10^{5}$ & $3.79 \times 10^{5}$ & $2.83 \times 10^{5}$ & $1.84 \times 10^{5}$ & $2.90 \times 10^{5}$ & $2.35 \times 10^{5}$ & $5.11 \times 10^{4}$ & $3.65 \times 10^{4}$ \\
\hline SPVdF/SPAni (85/15) blend & $9.11 \times 10^{5}$ & $7.49 \times 10^{5}$ & $5.21 \times 10^{5}$ & $4.02 \times 10^{5}$ & $5.01 \times 10^{5}$ & $4.29 \times 10^{5}$ & $1.51 \times 10^{5}$ & $6.66 \times 10^{4}$ \\
\hline SPVdF/SPAni (80/20) blend & $3.27 \times 10^{6}$ & $1.58 \times 10^{6}$ & $1.01 \times 10^{6}$ & $7.78 \times 10^{5}$ & $8.72 \times 10^{5}$ & $6.46 \times 10^{5}$ & $3.86 \times 10^{5}$ & $1.26 \times 10^{5}$ \\
\hline SPVdF/Nafion/SPAni ternary blend & $1.44 \times 10^{6}$ & $1.17 \times 10^{6}$ & $8.02 \times 10^{5}$ & $2.83 \times 10^{5}$ & $7.59 \times 10^{5}$ & $3.12 \times 10^{5}$ & $1.58 \times 10^{5}$ & $6.47 \times 10^{4}$ \\
\hline
\end{tabular}

Abbreviations: SPAni, partially sulfonated polyaniline; SPVdF, partially sulfonated poly(vinylidene fluoride). 


\section{CONCLUSIONS}

The incorporation of SPAni within the SPVdF matrix, to form SPVdF/ SPAni blend membranes, resulted in increasing the \%WU, the \%SR, the IEC and the proton conductivity of the base SPVdF membrane. In addition, the \%MUs and the methanol permeability values of the blend membranes were found to be considerably lower than those exhibited by the pristine SPVdF membrane. In addition, the proton conductivity values of the blend membranes were higher, and the methanol permeability values were lower than those of the pristine SPVdF membrane; therefore, the blend membrane selectivity values were much higher than those exhibited by the pristine SPVdF membrane. The effects of the incorporation of SPAni on the different membrane properties were clearly illustrated with varying SPAni content. The SPVdF/SPAni $(80 / 20)$ blend membrane was found to produce the lowest methanol permeability values of $1.50 \times 10^{-9}$ $\mathrm{cm}^{2} \mathrm{~s}^{-1}$ (at $2 \mathrm{M}$ methanol) and $6.30 \times 10^{-9} \mathrm{~cm}^{2} \mathrm{~s}^{-1}$ (at $8 \mathrm{M}$ methanol) and the highest membrane selectivity values of $3.27 \times 10^{6} \mathrm{Ss} \mathrm{cm}^{-3}$ (at $2 \mathrm{M}$ methanol) and $7.78 \times 10^{5} \mathrm{Ss} \mathrm{cm}^{-3}$ (at $8 \mathrm{M}$ methanol). However, the introduction of Nafion to the SPVdF/SPAni blend membrane, which formed a ternary blend membrane (that is, SPVdF:Nafion: SPAni $=50: 30: 20$ ), resulted in much improved IEC (that is, $0.72 \mathrm{meq} \mathrm{g}^{-1}$ ) and proton conductivity (that is, $1.01 \times 10^{-2} \mathrm{~S} \mathrm{~cm}^{-1}$ ).

\section{CONFLICT OF INTEREST}

The authors declare no conflict of interest.

\section{ACKNOWLEDGEMENTS}

KD thanks the Council of Scientific and Industrial Research (CSIR), India for a Senior Research Fellowship (Award no. 09/028 (0901)/2012-EMR-I). PPK thanks the Ministry of New and Renewable Energy (MNRE), Government of India for a Grant-in-Aid (Grant no. 102/56/2009-NT). We thank Mr Sujoy Debnath (University of Calcutta) for carrying out the tensile testing of the membranes.

1 Dutta, K., Kumar, P., Das, S. \& Kundu, P. P. Utilization of conducting polymers in fabricating polymer electrolyte membranes for application in direct methanol fuel cells. Polym. Rev. 54, 1-32 (2014).

2 Zhang, H. \& Shen, P. K. Recent development of polymer electrolyte membranes for fuel cells. Chem. Rev. 112, 2780-2832 (2012).

3 Zhang, H., Huang, H. \& Shen, P. K. Methanol-blocking Nafion composite membranes fabricated by layer-by-layer self-assembly for direct methanol fuel cells. Int. J. Hydrogen Energy 37, 6875-6879 (2012).

4 Zhao, C., Lin, H., Zhang, Q. \& Na, H. Layer-by-layer self-assembly of polyaniline on sulfonated poly(arylene ether ketone) membrane with high proton conductivity and low methanol crossover. Int. J. Hydrogen Energy 35, 10482-10488 (2010).

5 Ahn, K., Kim, M., Kim, K., Oh, I., Ju, H. \& Kim, J. Low methanol permeable crosslinked sulfonated poly(phenylene oxide) membranes with hollow glass microspheres for direct methanol fuel cells. Polymer 56, 178-188 (2015).

6 Ahn, K., Kim, M., Kim, K., Ju, H., Oh, I. \& Kim, J. Fabrication of low-methanolpermeability sulfonated poly(phenylene oxide) membranes with hollow glass microspheres for direct methanol fuel cells. J. Power Sources 276, 309-319 (2015).

7 Wang, C.-H., Chen, C.-C., Hsu, H.-C., Du, H.-Y., Chen, C.-P., Hwang, J.-Y., Chen, L. C., Shih, H.-C., Stejskal, J. \& Chen, K. H. Low methanol-permeable polyaniline/Nafion composite membrane for direct methanol fuel cells. J. Power Sources 190, 279-284 (2009).

8 Kumar, P., Dutta, K., Das, S. \& Kundu, P. P. An overview of unsolved deficiencies of direct methanol fuel cell technology: factors and parameters affecting its widespread use. Int. J. Energy Res. 38, 1367-1390 (2014).

9 Dutta, K., Das, S. \& Kundu, P. P. Synthesis, preparation and performance of blends and composites of $\pi$-conjugated polymers and their copolymers in DMFCs. Polym. Rev. 55, 630-677 (2015).

10 Cho, K.-Y., Jung, H.-Y., Sung, K. A., Kim, W.-K., Sung, S.-J., Park, J.-K., Choi, J.-H. \& Sung, Y.-E. Preparation and characteristics of Nafion membrane coated with a PVdF copolymer/recast Nafion blend for direct methanol fuel cell. J. Power Sources 159, 524-528 (2006).

11 Cho, K.-Y., Eom, J.-Y., Jung, H.-Y., Choi, N.-S., Lee, Y. M., Park, J.-K., Choi, J.-H., Park, K.-W. \& Sung, Y.-E. Characteristics of PVdF copolymer/Nafion blend membrane for direct methanol fuel cell (DMFC). Electrochim. Acta 50, 583-588 (2004).
12 Kumar, G. G., Lee, D. N., Kim, P., Nahm, K. S. \& Elizabeth, R. N. Characterization of $\mathrm{PVdF}-\mathrm{HFP} / \mathrm{Nafion} / \mathrm{AIO}[\mathrm{OH}]_{n}$ composite membranes for direct methanol fuel cell (DMFC). Eur. Polym. J. 44, 2225-2230 (2008).

13 Pereira, F., Chan, A., Vallé, K., Palmas, P., Bigarré, J., Belleville, P. \& Sanchez, C Design of interpenetrated networks of mesostructured hybrid silica and nonconductive poly(vinylidene fluoride)-cohexafluoropropylene (PVdF-HFP) polymer for proton exchange membrane fuel cell applications. Chem. Asian J. 6, 1217-1224 (2011).

14 Kumar, G. G., Shin, J., Nho, Y.-C., seon Hwang, I., Fei, G., Kim, A. R. \& Nahm, K. S. Irradiated PVdF-HFP-tin oxide composite membranes for the applications of direct methanol fuel cells. J. Membr. Sci. 350, 92-100 (2010).

15 Corti, H. R. \& Gonzalez, E. R. (eds). Direct Alcohol Fuel Cells: Materials, Performance, Durability and Applications IX, 370 (Springer, Netherlands, 2014).

16 Li, M., Zhang, G., Xu, S., Zhao, C., Han, M., Zhang, L., Jiang, H., Liu, Z. \& Na, H. Cross-linked polyelectrolyte for direct methanol fuel cells applications based on a novel sulfonated cross-linker. J. Power Sources 255, 101-107 (2014).

17 Xu, D., Zhang, G., Zhang, N., Li, H., Zhang, Y., Shao, K., Han, M., Lew, C. M. \& Na, H. Surface modification of heteropoly acid/SPEEK membranes by polypyrrole with a sandwich structure for direct methanol fuel cells. J. Mater. Chem. 20, 9239-9245 (2010).

18 Neelakandan, S., Rana, D., Matsuura, T., Muthumeenal, A., Kanagaraj, P. \& Nagendran, A. Fabrication and electrochemical properties of surface modified sulfonated poly(vinylidenefluoride-co-hexafluoropropylene) membranes for DMFC application. Solid State Ionics 268, 35-41 (2014).

19 Mokrini, A. \& Huneault, M. A. Proton exchange membranes based on PVDF/ SEBS blends. J. Power Sources 154, 51-58 (2006).

20 Zhang, Y., Cai, W., Si, F., Ge, J., Liang, L., Liu, C. \& Xing, W. A modified Nafion membrane with extremely low methanol permeability via surface coating of sulfonated organic silica. Chem. Commun. 48, 2870-2872 (2012).

21 Diaz, L. A., Abuin, G. C. \& Corti, H. R. Methanol sorption and permeability in Nafion and acid-doped $\mathrm{PBI}$ and $\mathrm{ABPBI}$ membranes. J. Membr. Sci. 411-412, 35-44 (2012).

22 Peighambardoust, S. J., Rowshanzamir, S. \& Amjadi, M. Review of the proton exchange membranes for fuel cell applications. Int. J. Hydrogen Energy 35, 9349-9384 (2010)

23 Sahu, A. K., Bhat, S. D., Pitchumani, S., Sridhar, P., Vimalan, V., George, C., Chandrakumar, N. \& Shukla, A. K. Novel organic-inorganic composite polymerelectrolyte membranes for DMFCs. J. Membr. Sci. 345, 305-314 (2009).

24 Ahmed, M. \& Dincer, I. A review on methanol crossover in direct methanol fuel cells: challenges and achievements. Int. J. Energy Res. 35, 1213-1228 (2011).

25 Liu, F., Hashim, N. A., Liu, Y., Abed, M. R. M. \& Li, K. Progress in the production and modification of PVDF membranes. J. Membr. Sci. 375, 1-27 (2011).

26 Kumar, P., Dutta, K., Das, S. \& Kundu, P. P. Membrane prepared by incorporation of crosslinked sulfonated polystyrene in the blend of PVdF-Co-HFP/Nafion: a preliminary evaluation for application in DMFC. Appl. Energy 123, 66-74 (2014).

27 Das, S., Kumar, P., Dutta, K. \& Kundu, P. P. Partial sulfonation of PVdF-co-HFP: a preliminary study and characterization for application in direct methanol fuel cell. Appl. Energy 113, 169-177 (2014).

28 Dutta, K., Das, S., Kumar, P. \& Kundu, P. P. Polymer electrolyte membrane with high selectivity ratio for direct methanol fuel cells: a preliminary study based on blends of partially sulfonated polymers polyaniline and PVdF-co-HFP. Appl. Energy 118, 183-191 (2014).

29 Dutta, K., Das, S. \& Kundu, P. P. Low methanol permeable and highly selective membranes composed of pure and/or partially sulfonated PVdF-co-HFP and polyaniline. J. Membr. Sci. 468, 42-51 (2014).

30 Dutta, K., Das, S. \& Kundu, P. P. Partially sulfonated polyaniline induced high ionexchange capacity and selectivity of Nafion membrane for application in direct methanol fuel cells. J. Membr. Sci. 473, 94-101 (2015).

31 Mondal, S., Soam, S. \& Kundu, P. P. Reduction of methanol crossover and improved electrical efficiency in direct methanol fuel cell by the formation of a thin layer on Nafion 117 membrane: effect of dip-coating of a blend of sulphonated PVdF-co-HFP and PBI. J. Membr. Sci. 474, 140-147 (2015).

32 Das, S., Dutta, K. \& Kundu, P. P. Partially sulfonated poly(vinylidene fluoride) induced enhancements of properties and DMFC performance of Nafion electrolyte membrane. Fuel Cells 15, 505-515 (2015).

33 Dutta, K., Mahale, R. Y., Arulkashmir, A. \& Krishnamoorthy, K. Reversible assembly and disassembly of micelles by a polymer that switches between hydrophilic and hydrophobic wettings. Langmuir 28, 10097-10104 (2012).

34 Das, S., Dutta, K. \& Kundu, P. P. Nickel nanocatalysts supported on sulfonated polyaniline: potential toward methanol oxidation and as anode materials for DMFCs. J. Mater. Chem. A 3, 11349-11357 (2015).

35 Kumar, P., Dutta, K. \& Kundu, P. P. Enhanced performance of direct methanol fuel cells: a study on the combined effect of various supporting electrolytes, flow channel designs and operating temperatures. Int. J. Energy Res. 38, 41-50 (2014).

36 Becker, C. M., Biagini, A. B., Forte, M. M. C., Amico, S. C., Vargas, J. V. C. \& Azambuja, D. S. Sulfonation and characterization of styrene-indene copolymers for the development of proton conducting polymer membranes. Polímeros 22, 395-400 (2012).

$37 \mathrm{Li}$, X., Liu, C., Lu, H., Zhao, C., Wang, Z., Xing, W. \& Na, H. Preparation and characterization of sulfonated poly(ether ether ketone ketone) proton exchange membranes for fuel cell application. J. Membr. Sci. 255, 149-155 (2005).

38 Nasef, M. M. \& Aly, A. A. Water and charge transport models in proton exchange membranes: an overview. Desalination 287, 238-246 (2012).

39 Kreuer, K.-D. Proton conductivity: materials and applications. Chem. Mater. 8, 610-641 (1996). 
40 Song, M.-K., Kim, Y.-T., Fenton, J. M., Kunz, H. R. \& Rhee, H.-W. Chemically-modified Nafion $\%$ poly(vinylidene fluoride) blend ionomers for proton exchange membrane fuel cells. J. Power Sources 117, 14-21 (2003).

41 Zhou, H., Wang, H., Niu, H., Gestos, A. \& Lin, T. Robust, self-healing superamphiphobic fabrics prepared by two-step coating of fluoro-containing polymer, fluoroalkyl silane, and modified silica nanoparticles. Adv. Funct. Mater. 23, 1664-1670 (2013).

42 Kim, H. J., Kim, H. J., Shul, Y. G. \& Han, H. S. Nafion-Nafion/polyvinylidene fluorideNafion laminated polymer membrane for direct methanol fuel cells. J. Power Sources 135, 66-71 (2004).

43 Lehtinen, T., Sundholm, G., Holmberg, S., Sundholm, F., Björnbom, P. \& Bursell, M. Electrochemical characterization of PVDF-based proton conducting membranes for fuel cells. Electrochim. Acta 43, 1881-1890 (1998).

44 Dutta, K. \& Kundu, P. P. Amphiphiles as hydrophobicity regulator: fine tuning the surface hydrophobicity of an electropolymerized film. J. Colloid Interface Sci. 397, 192-198 (2013).

45 Dutta, K. \& Kundu, P. P. Interaction between oxidized polyaniline and oppositely charged amphiphilic assemblies in an aqueous/organic biphasic system. J. Colloid Interface Sci. 407, 516-523 (2013).

46 Dutta, K. \& Kundu, P. P. Reversible assembly and disassembly of amphiphilic assemblies by electropolymerized polyaniline films: effects rendered by varying the electropolymerization potential. J. Phys. Chem. B 117, 7797-7805 (2013).

47 Dutta, K., Kumar, P., Das, S. \& Kundu, P. P. Effects of various factors on the interfacial mass transfer phenomenon and dispersion of polyaniline in an aqueous/organic bi-/tri-phasic system. Colloids Surf. A Physicochem. Eng. Aspects 436, 830-838 (2013).

48 Dutta, K., Das, S., Rana, D. \& Kundu, P. P. Enhancements of catalyst distribution and functioning upon utilization of conducting polymers as supporting matrices in DMFCs: a review. Polym. Rev. 55, 1-56 (2015).

49 Dutta, K. \& Kundu, P. P. A review of aromatic conducting polymers-based catalyst supporting matrices for application in microbial fuel cells. Polym. Rev. 54, 401-435 (2014).

50 Pei, H., Hong, L. \& Lee, J. Y. Effects of polyaniline chain structures on proton conduction in a PEM host matrix. J. Membr. Sci. 307, 126-135 (2008).

51 Yang, Z., Coutinho, D. H., Sulfstede, R., Balkus, K. J. Jr. \& Ferraris, J. P. Proton conductivity of acid-doped meta- polyaniline. J. Membr. Sci. 313, 86-90 (2008).

52 Cho, K.-Y., Jung, H.-Y., Choi, N.-S., Sung, S.-J., Park, J.-K., Choi, J.-H. \& Sung, Y.-E. A coated Nafion membrane with a PVdF copolymer/Nafion blend for direct methanol fuel cells (DMFCs). Solid State Ionics 176, 3027-3030 (2005).

53 Ramya, K. \& Dhathathreyan, K. S. Direct methanol fuel cells: Determination of fuel crossover in a polymer electrolyte membrane. J. Electroanal. Chem. 542, 109-115 (2003).

54 Huang, Q. M., Zhang, Q. L., Huang, H. L., Li, W. S., Huang, Y. J. \& Luo, J. L. Methanol permeability and proton conductivity of Nafion membranes modified electrochemically with polyaniline. J. Power Sources 184, 338-343 (2008).

55 Chen, C.-Y., Garnica-Rodriguez, J. I., Duke, M. C., Costa, R. F. D., Dicks, A. L. \& da Costa, J. C. D. Nafion/polyaniline/silica composite membranes for direct methanol fuel cell application. J. Power Sources 166, 324-330 (2007).

Supplementary Information accompanies the paper on Polymer Journal website (http://www.nature.com/pj) 